\title{
ĀTRAUDZīGO KOKU STĀDĪJUMU IZVĒRTĒJUMS, IZMANTOJOT AHP METODI
}
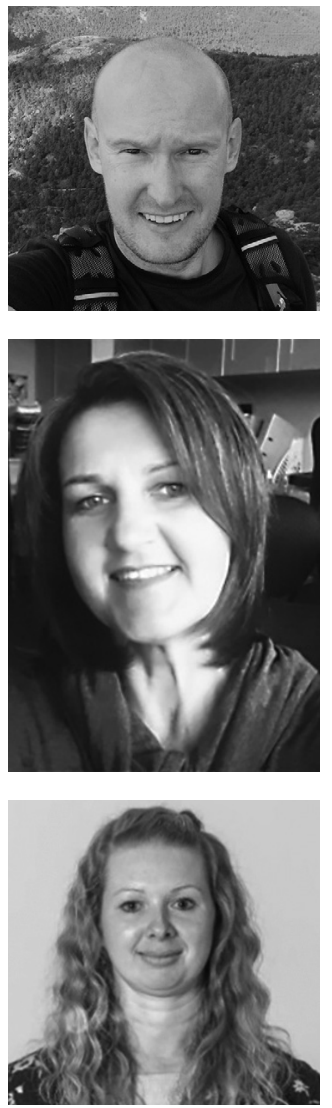

Kristaps Makovskis ir ieguvis $B c$. silv. akadēmisko grādu Latvijas Lauksaimniecības universitātes (LLU) Meža fakultātē un $M g$. oec. akadēmisko grādu LLU Ekonomikas un sabiedrības attīstības fakultātē. Pašreiz strādā par zinātnisko asistentu Latvijas Valsts mežzinātnes institūtā (LVMI) Silava meža atjaunošanas un ieaudzēšanas darba grupā.

Dagnija Lazdiṇa ir ieguvusi $B c$. biol. un $M g$. biol. akadēmisko grādu LU Bioloğijas fakultātē, pētot $\mathrm{NaCl}$ izraisīto stresu Rhododendron Nova Zembla šķirnes mikrospraudeniem in vitro apstākḷos. Kā LVMI Silava zinātniskā asistente izstrādājusi promocijas darbu Notekūdeñu dūnฺ izmantošanas iespējas kārklu plantācijās LLU Meža fakultātē, iegūstot mežzinātnes doktores zinātnisko grādu. Pašreiz ir vadošā pētniece LVMI Silava meža atjaunošanas, ieaudzēšanas un kokaugu stādījumu ārpus meža zemēm radošajā grupā. Aktuālie pêtīijumi saistīti ar bioekonomikas jautājumiem par meža atjaunošanu un ieaudzēšanu, kokaugu stādījumu veikšanu marginālās platībās un derīgo izrakteṇu karjeru rekultivāciju, stādot kokus, ieskaitot šo darbu mašinizācijas iespējas. Latvijas Zinātnes padomes eksperte vides biotehnolog̣ijas, vides inženierijas un enerǵêtikas, lauksaimniecības un mežzinātnes nozarē. Zinātnisku un populārzinātnisku rakstu un monogrāfiju nodaḷu autore.

Dina Popluga ir ekonomikas doktore, asociētā profesore un pētniece LLU Ekonomikas un sabiedrības attīstîbas fakultātē. Eksperte klimata politikas un vides jautājumos attiecībā uz lauksaimniecību. 36 zinātniskas publikācijas un pieredze 15 projektu îstenošanā.

Raksturvārdi: koku stādījumi, kārklu stādījumi, apšu hibrīdu stādījumi, kokaugu stādījumi, agromežsaimniecības stādījumi.

\section{Ievads}

Biomasa ir galvenais atjaunojamās energijas avots Eiropas Savienībā, kas veido $63,8 \%$ no visiem atjaunojamajiem resursiem. ${ }^{1}$
Lai samazinātu oglekḷa emisijas nākotnē, par vienu no instrumentiem mērķa sasniegšanai tiek uzskatîta biomasas izmantošanas palielināšana enerǵijas ražošanā. Ātraudzīgo koku stādījumu ierīkošana ir viens no veidiem, kā veicināt siltumnīcefektu gāzu emisiju samazināšanu un palielināt atjaunojamās enerǵijas izmantošanu siltumenerğijas un elektroenerǵijas ražošanā. ${ }^{2}$ Pēc Lauku atbalsta dienesta 
datiem, 2017. gadā no 2252043 hektāriem lauksaimniecībā izmantojamās zemes (LIZ) $12,4 \%$ tika uzskaitīti kā nekoptas LIZ. ${ }^{3}$ Daļa šo platību šobrīd netiek izmantotas ražošanā un nākotnē varētu tikt izmantotas biomasas ražošanai. Ātraudzīgo stādījumu ierīkošana palielinās darbavietu skaitu lauku apvidos, kā arī nodrošinās darbaspēka izmantošanas iespējas ziemas periodā, kad notiek koku stādījumu biomasas novākšana un nenotiek citu lauksaimniecības produktu novākšana.

Parādoties efektīvākam zemes izmantošanas veidam, rekultivējot platības, zemes platības iespējams atgriezt atpakaļ lauksaimniecības produktu ražošanai piemērotās platībās. ${ }^{4}$ Latvijas apstākḷıs piemērotākās sugas àtraudzīgo stādījumu ierīkošanai ir kārkls (Salix spp.), hibrīdā apse (Populus spp.), papele (Populus spp.) un baltalksnis (Alnus incana).

\section{Metodika}

Lai vispusīgi novērtētu Latvijas apstākliiem piemērotākos ātraudzīgo koku stādījumu veidus, tika izmantota amerikāṇu matemātiķa T. Saati aprakstītā hierarhiju analīzes metode (The Analytic Hierarchy Process). ${ }^{5}$ AHP metode ir matemātiski pamatota, un tā ḷauj iegūt objektīvus rezultātus, pamatojoties uz aptaujāto ekspertu vērtējumiem.
Lai veiktu AHP analīzi, tika aptaujāti šādi eksperti:

1) Mudrīte Daugaviete - LVMI Silava vadošā pētniece;

2) Mārtiņš Zeps - LVMI Silava pētnieks;

3) Andis Lazdiņš - LVMI Silava vadošais pētnieks;

4) Andis Bārdulis - LVMI Silava pētnieks, zemnieku saimniecības Andrupēni īpašnieks;

5) Aldis Jansons - LLU Zemkopības zinātniskā institūta vadošais pētnieks, direktors;

6) Jānis Vigovskis - LLU Zemkopības zinātniskā institūta vadošais pētnieks;

7) Ingūna Krīgere - Latvijas Kūdras asociācijas valdes locekle;

8) Jovita Pilecka - LLU Vides un ūdenssaimniecības katedras pētnieka asistente, vieslektore;

9) Inga Grīnfelde - LLU Vides un ūdenssaimniecības katedras docente;

10) Uldis Ameriks - SIA Laflora valdes priekšsēdētājs;

11) Jānis Knipsis - Mazo meža īpašnieku biedrības valdes priekšsēdētājs. ${ }^{6,7,8}$

Metodes pirmajā līmen⿳亠 tika izvirzìts mērķis - lauksaimniecībā neizmantotās zemes izmantošana ātraudzịgo koku audzēšanai. Otrajā līmenī ekspertiem tika dots uzdevums novērtēt ekonomiskos, sociālos, vides vai

\section{1. tabula. Faktoru ietekmējošie kritēriji saistībā ar sasniedzamo mērḳi}

\begin{tabular}{ll}
\hline Ekonomisko faktoru kritēriji & Sociālo faktoru kritēriji \\
\hline - Sākotnējās investīcijas & - Lauku ainavas dažādošana \\
- Ekonomiskais ieguvums & - Cilvēku piesaiste lauku reğioniem \\
- Darbaspēka pieejamība & - Jaunu zināšanu ienese lauku reğionos \\
- Atbalsta maksājumi & - Sadarbības veicināšana \\
\hline Vides faktoru kritēriji & Tehnoloğisko faktoru kritēriji \\
\hline - Bioloğiskā daudzveidība & - Tehnikas pieejamība biomasas ražošanai \\
- Oglekḷa piesaiste & - Iekārtu pieejamība biomasas izmantošanai \\
- Augsnes kvalitātes uzlabošana & Piemērotu platību pieejamība \\
- Atjaunojamo resursu izmantošana & - Zināšanu pieejamība \\
\hline
\end{tabular}

\footnotetext{
Lazdina 2009, 58.

Saaty 1981 .
}

\author{
Lēnerts 2018. \\ Platonova 2016. \\ Pelše 2007.
}




\section{2. tabula. Ātraudzīgo koku stādījumu alternatīvas stādījumu ierīkošanai}

lauksaimniecībā neizmantotās zemēs

\begin{tabular}{|c|c|c|}
\hline $\begin{array}{l}\text { Nr. } \\
\text { p. } k \text {. }\end{array}$ & $\begin{array}{c}\text { Ātraudzīgo koku } \\
\text { stādījumu veids }\end{array}$ & Apraksts \\
\hline 1. & $\begin{array}{l}\text { Ekstensīvi apsaimniekoti } \\
\text { kārklu stādījumi } \\
\text { (Manuāla novākšana) }\end{array}$ & $\begin{array}{l}\text { Stādījums tiek audzēts } 25 \text { gadus ar aprites periodu četri gadi. Kārkli tiek } \\
\text { novākti manuāli, izmantojot rokas instrumentus, un pievesti lauka malā } \\
\text { ar traktortehniku. Kārklu stumbri tiek šǩeldoti ar mobilo šķeldotāju, } \\
\text { iekrauti transporta mašīnās un piegādāti patērētājam. Galvenais stādījumu } \\
\text { produkts ir koksnes šķeldas }\end{array}$ \\
\hline 2. & $\begin{array}{l}\text { Intensīvi apsaimniekoti } \\
\text { kārklu stāī̄jumi } \\
\text { (Industriāla novākšana) }\end{array}$ & $\begin{array}{l}\text { Stādījums tiek audzēts } 25 \text { gadus ar aprites periodu trīs gadi. Kārkli tiek } \\
\text { novākti ar pḷaušanas kombainu, kas vienlaicīgi pḷauj un škeldo piekabē. } \\
\text { Līdz lauka malai šḳeldas tiek aizvestas ar traktortehniku. Pēc uzglabāšanas } \\
\text { šķeldas tiek iekrautas transporta mašīnās un piegādātas patērētājam. Pēc } \\
\text { katras plaušanas platīiba tiek ielabota ar koksnes pelniem, kurus iespējams } \\
\text { iegūt no tuvākajām katlumājāām (visbiežāk bez maksas, parasti sedzot } \\
\text { tikai transporta izdevumus līdz izkasišanas vietai). Galvenais stādījumu } \\
\text { produkts ir koksnes šķeldas }\end{array}$ \\
\hline 3. & $\begin{array}{l}\text { Apses hibrīdu kokaugu } \\
\text { stādījums }\end{array}$ & $\begin{array}{l}\text { Stādījums tiek audzēts } 30 \text { gadus ar aprites periodu } 15 \text { gadi. Otrā aprite tiek } \\
\text { audzēta no atvasēm. Stādījumu produkti ir papīrmalka, malka un koksnes } \\
\text { šķeldas }\end{array}$ \\
\hline 4. & $\begin{array}{l}\text { Apses hibrīidu } \\
\text { agromežsaimniecības } \\
\text { stādījums }\end{array}$ & $\begin{array}{l}\text { Stādījums tiek audzēts } 30 \text { gadus ar aprites periodu } 15 \text { gadi. Pirmos piecus } \\
\text { gadus apses hibrīdi tiek audzēti kopā ar daudzgadīgajiem zālaugiem, kuri } \\
\text { ir iesēti starp koku rindām. Pirmos piecus gadus tiek ievāktas zālaugu } \\
\text { sēklas, kas tiek pārdotas. Otrā aprite tiek audzēta no atvasēm. Stādījumu } \\
\text { produkti ir zālaugu sēklas, papīrmalka, malka un koksnes šḳeldas }\end{array}$ \\
\hline 5. & $\begin{array}{l}\text { Apses hibrīdu plantāciju } \\
\text { mežs }\end{array}$ & $\begin{array}{l}\text { Stādījums tiek audzēts } 40 \text { gadus ar aprites periodu } 20 \text { gadi. Otrā aprite tiek } \\
\text { audzēta no atvasēm. Stādījumu produkti ir zāgabalı̣ki, papīrmalka, malka un } \\
\text { koksnes šķeldas }\end{array}$ \\
\hline
\end{tabular}

tehnoloǵiskos faktorus, kas ietekmē mērḳa sasniegšanu. Katram faktoram tika izvirzīti četri kritēriji, pēc kuriem novērtēt stādījumu veidu. Kritēriji tika noteikti pirms aptaujas, un ekspertiem nebija iespējams izmainīt esošos vai pievienot jaunus kritērijus. Trešajā metodes līmenī eksperti noteica iepriekš izvirzîto faktoru ietekmējošo kritēriju svarīgumu saistībā ar sasniedzamo mērḳi (1. tabula).

Metodes ceturtajā līmen̄̄ ekspertiem tika piedāvāti pieci varianti lauksaimniecībā neizmantotās zemes izmantošanai àtraudzīgo koku stādījumiem (2. tabula).

Pirms aptaujas eksperti tika iepazīstināti ar analītiskās hierarhijas metodes teorētisko pamatojumu un pētījuma aktualitāti. Aptaujas anketas tika aizpildītas elektroniski vai tiekoties personiski ar ekspertu.

Izmantojot AHP metodi, iespējams sarežǵītu un nestrukturētu problēmu sadalīt komponentos un, izmantojot iepriekš izvēlētu ekspertu zināšanas un pieredzi, iegūt zinātniski pamatotus rezultātus. ${ }^{9} \breve{S}_{1}$ metode iepriekš izmantota līdzīgos pētījumos par dažādiem zemes apsaimniekošanas scenārijiem un piemērotāko scenāriju izvēli. ${ }^{10,11}$

\section{Rezultāti un secinājumi}

Ekspertu vērtējumu apkopo, aprēkininot katra vērtējuma aritmētisko vidējo un izkliedi. Izkliede tiek attēlota kā amplitūda no minimālās līdz maksimālajai vērtībai katrā konkrētajā vērtējumā. Izvērtējot faktorus, eksperti ekonomiskās grupas faktorus ir vērtējuši augstāk $(0,52)$, salīdzinot ar tehnologiskajiem $(0,18)$,

\footnotetext{
9 Lēnerts 2018.

10 Turpat.

$11 \quad$ Platonova 2016.
} 


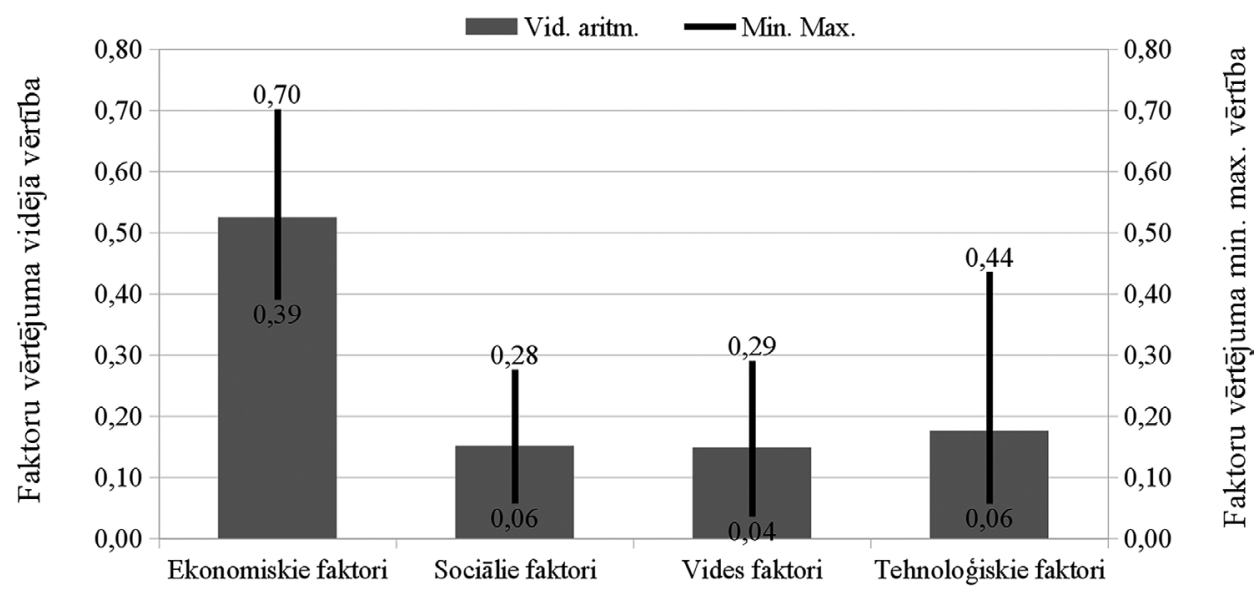

1. attēls. Lauksaimniecībā neizmantotās zemes izmantošana ātraudzīgo koku stādījumu audzēšanai. Ekspertu vērtējums par ekonomiskajiem, sociālajiem, vides un tehnoloğiskajiem faktoriem

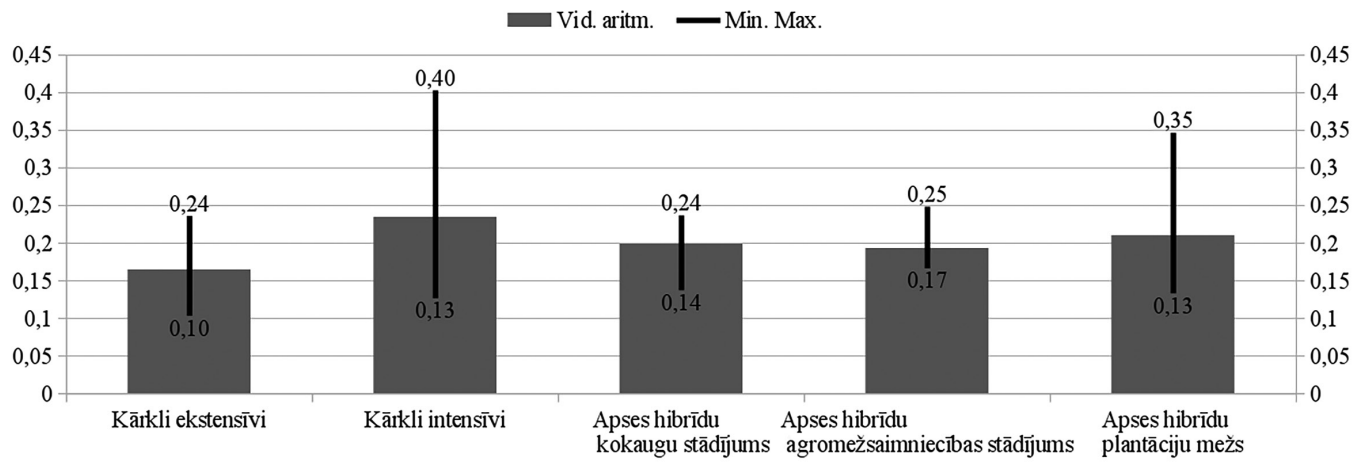

2. attēls. Ekspertu vērtējums par piemērotāko ātraudzīgo koku stādījumu veidu lauksaimniecībā neizmantotās zemēs

vides $(0,15)$ un sociālajiem faktoriem $(0,15)$ (1. attēls).

Vērtējot kritēriju nozīmi ekonomiskajā faktorā, nozīmīgākais kritērijs ekspertu vērtējumā ir ekonomiskais ieguvums $(0,44)$, tālāk seko sākotnējais investīciju apjoms $(0,27)$, atbalsta maksājumi $(0,18)$ un darbaspēka pieejamība $(0,12)$. Vērtējot tehnoloǵiskos kritērijus, būtiskākais ir piemērotu platību pieejamība $(0,43)$, tālāk seko iekārtu pieejamība biomasas izmantošanai $(0,24)$, zināšanu pieejamība $(0,18)$ un tehnikas pieejamība biomasas ražošanai $(0,15)$. Būtiskākais sociālais kritērijs ir cilvēku piesaiste lauku reǵioniem $(0,38)$, kam seko jaunu zināšanu ienese lauku reǵionos $(0,23)$, lauku ainavas dažādošana $(0,21)$ un sadarbības veicināšana $(0,18)$. Būtiskākais vides kritērijs ir augsnes kvalitātes uzlabošana $(0,31)$, kam seko atjaunojamo resursu izmantošana $(0,27)$, oglekḷa piesaiste $(0,23)$ un bioloǵiskā daudzveid̄iba $(0,19)$.

Izvērtējot piecus dažādus ātraudzīgo koku stādījumu veidus, par piemērotāko izmantošanai lauksaimniecībā neizmantotās zemēs eksperti atzina intensīvi apsaimniekotu kārklu stādījumu ierīkošanu $(0,24)$, kurš tajā pašā laikā tika vērtēts vispretrunīgāk (ar vislielāko izkliedi). Tālāk seko apses hibrīdu plantāciju mežs $(0,21)$, kokaugu stādījums $(0,20)$ un agromežsaimniecības stādījums $(0,19)$, kuri visi tiek vērtēti salīdzinošo līdzīgi. Viszemāk tiek vērtēts kārklu stādījums, kurš tiek apsaimniekots ekstensīvi $(0,16)$, lai arī tā vērtējums ir ar vismazāko izkliedi (2. attēls). 
Ekspertu vērtējumi liek secināt, ka ekonomiskie faktori ir svarīgākie, tas jāṇem vērā, izvēloties kādu no stādījumu veidiem. Negūstot ienākumus no konkrētā stādījumu veida stādījumiem, zemes īpašnieks visticamāk izvēlēsies citu stādījumu vai citu zemes izmantošanas veidu.
Raksta tapšanā tika izmantots finansējums no Eiropas Savienības pētniecības un inovācijas programmas Apvārsnis 2020 atbalstītā projekta Biomateriālu izmantošanas stratēgijas un cel̦veži ES lauku un régionālās attīstības uzlabošanai (BE-Rural) (Nr. 818478).

\section{VĒRES}

Bioenergy Europe: Statistical Report (2018) The European Pellet Council (EPC).

Lauku atbalsta dienests (2017) LIZ apsekošanas rezultāti novadu griezumā, 2017. gads. Pieejams: http:// www.lad.gov.lv/files/zva_17_gat_tabula.pdf (18.07.2019.).

Lazdiṇa, D. (2009) Notekūdenu dūṇu izmantošanas iespējas kārklu plantācijās (Usage of Sewage Sludge in Willow Plantations). Promocijas darba kopsavilkums Dr. silv. zinātniskā grāda iegūšs̆anai mežzinātnes nozarē, meža ekologijas un mežkopības apakšnozarē. Jelgava : Latvijas Lauksaimniecības universitāte.

Lēnerts, A. (2018) Siltumnīcefekta gāzu emisiju samazināšana - lauksaimniecības ilgtspējīgai attīstībai Latvijā. Promocijas darbs ekonomikas doktora (Dr. oec.) zinātniskā grāda iegūšsanai. Jelgava : Latvijas Lauksaimniecības universitāte.

Njakou Djomo S.; Ac, A.; Zenone, T.; De Groote, T.; Bergante, S.; Facciotto, G.; Sixto, H.; Ciria, P.; Weger, J.; Ceulemans, R. (2015) Energy performances of intensive and extensive short rotation cropping systems for woody biomass production in the EU. Renewable Sustainable Energy Reviews, 41, 845-854.

Pelše, M. (2007) Zemnieku sociālā kapitāla attīstības iespējamo scenāriju izvērtējums. LLU Raksti, 19 (314), 89-98.

Platonova, D. (2016) Ekspertu vērtējums par zemes degradācijas noteikšanas kritēriju savstarpējo ietekmi. Pieejams: https://www.lps.lv/uploads/docs module/4 Ekspertu\%20v\%C4\%93rt\%C4\%93jums\%20 par\%20zemes\%20degrad\%C4\%81 cijas\%20noteik\% C5\%Alanas\%20krit\%C4\%93riju\%20 savstarp\%C4\%93jo\%20ietekmi.pdf (18.07.2019.).

Saaty, T. (1981) The Analytic Hierarchy Process. USA. 